\title{
Study on Geomorphic Stage of Mt. Sanqingshan Geopark
}

\author{
Zhanghuang $\mathrm{Ye}^{\mathrm{a}, \mathrm{b}^{*}}$, Anjian Wang ${ }^{\mathrm{b}}$ and Qiang Yan ${ }^{\mathrm{b}}$
}

a Jiangxi Science and Technology Normal University, Nanchang, 330038, Jiangxi, PR China;

b Chinese Academy of Geological Sciences, Beijing,100037, PR China;

* Corresponding author at: chuckverna@sina.com

Keywords: Geomorphic stage; thermal-chronology; apatite; Mt. Sanqingshan

\begin{abstract}
Mt. Sanqingshan Geopark in Jiangxi is famous for its granite peak-forest landforms in the world. Low temperature thermal-chronology is used to analyze the uplifting and denudation process of Mt. Sanqingshan in the paper. The fission track ages can be divided into three groups, which can be related to the uplifting-denudation processes involved in forming ancient multilevel denudation planes. Mt. Sanqingshan underwent four stages of thermal evolution, approximately 90Ma to 60Ma, $60 \mathrm{Ma}$ to $40 \mathrm{Ma}, 40 \mathrm{Ma}$ to $15 \mathrm{Ma}, 15 \mathrm{Ma}$ to the present. The corresponding cooling rates are $1.95^{\circ} \mathrm{C} / \mathrm{Ma}, 1.17^{\circ} \mathrm{C} / \mathrm{Ma}, 0.35^{\circ} \mathrm{C} / \mathrm{Ma}, 3.72^{\circ} \mathrm{C} / \mathrm{Ma}$, with the average cooling rate of $1.81^{\circ} \mathrm{C} / \mathrm{Ma}$. The last stage is significantly faster than the other three stages, reflecting the faster uplifting of Mt. Sanqingshan under the new tectonic movement. The average uplifting rate in Mt. Sanqingshan is $0.052 \mathrm{~mm} / \mathrm{a}$, and the average denudation rate is $0.047 \mathrm{~mm} / \mathrm{a}$, with the gap of $0.005 \mathrm{~mm} / \mathrm{a}$. The average uplifting amount is $3500 \mathrm{~m}$, denudation $2500 \mathrm{~m}$, since the average apatite fission track age 56Ma. The gap is very close to the average elevation in Mt. Sanqingshan. This is the process from the magma emplacement $6 \mathrm{~km}$ underground to present medium-sized mountain. These features are consistent with geomorphology stages and geological evidences. Thermal-chronology has important constraint for different stages of granite landforms.

Mt. Sanqingshan is located in North latitude $28^{\circ} 48^{\prime} 22-29^{\circ} 00^{\prime} 45$, East longitude $117^{\circ} 58 ' 20-118^{\circ} 08^{\prime} 28$. The total area of the scenic spot is $229.5 \mathrm{~km} 2$. Yujing Peak is the highest, whose elevation is $1819.9 \mathrm{~m}$. Mt. Sanqingshan is an important tourist attraction in China with perfect combination of granite geology, landscape and ecology, extending in the south-north direction. The terrain height difference is big, whose slopes in the East, South and West are steep and slows down in the north. However, no studies have been conducted on the quantitative processes of the geomorphic evolution in Mt. Sanqingshan, but such studies in Mt. Sanqingshan will enhance the scientific significance of the Geopark.
\end{abstract}

\section{Geological setting}

Mt. Sanqingshan and the surrounding areas enjoys the Earth evolution history for more than 1 billion years, with almost continuous formations from Proterozoic to Quaternary, except the middle and upper Silurian strata, middle and lower Devonian strata, and the old Tertiary strata (Figure 1). It has experienced major geological events, such as Caledonian movement, Indo-China movement, Yanshan movement and Himalayas movement and changes from sea to land three times. Magmatic rocks have been well developed in the region. From late Jurassic to early Cretaceous, felsic magmatic eruption occurred in the southeast part of the region with the subduction of the Pacific plate, forming calc-alkaline volcanic rocks. In the extensional tectonic environment, massive felsic magma strongly intruded in Early Cretaceous, forming a large area of granite body.

The folds and faults structures in the region have been well developed too. Strong and repeated orogenic movements made the cover coat distorted, forming universal angular unconformities. Huangtuling anticlinorium and Huameishan syncline are the major folds in the region. Till Himalayan period the three normal faults (Fenglin-Zihu Fault, Xiaxikeng-Bajiaowu Fault, and Bajiaowu-Fenglin Fault) have been formed, cutting Mt. Sanqingshan granite body into a typical block mountain. In the interior of the granite body, there mainly exist joint groups with three directions (NE, NW and horizontal joints). In addition, Mesozoic intracontinental subduction has 
formed super-crust deep faults.

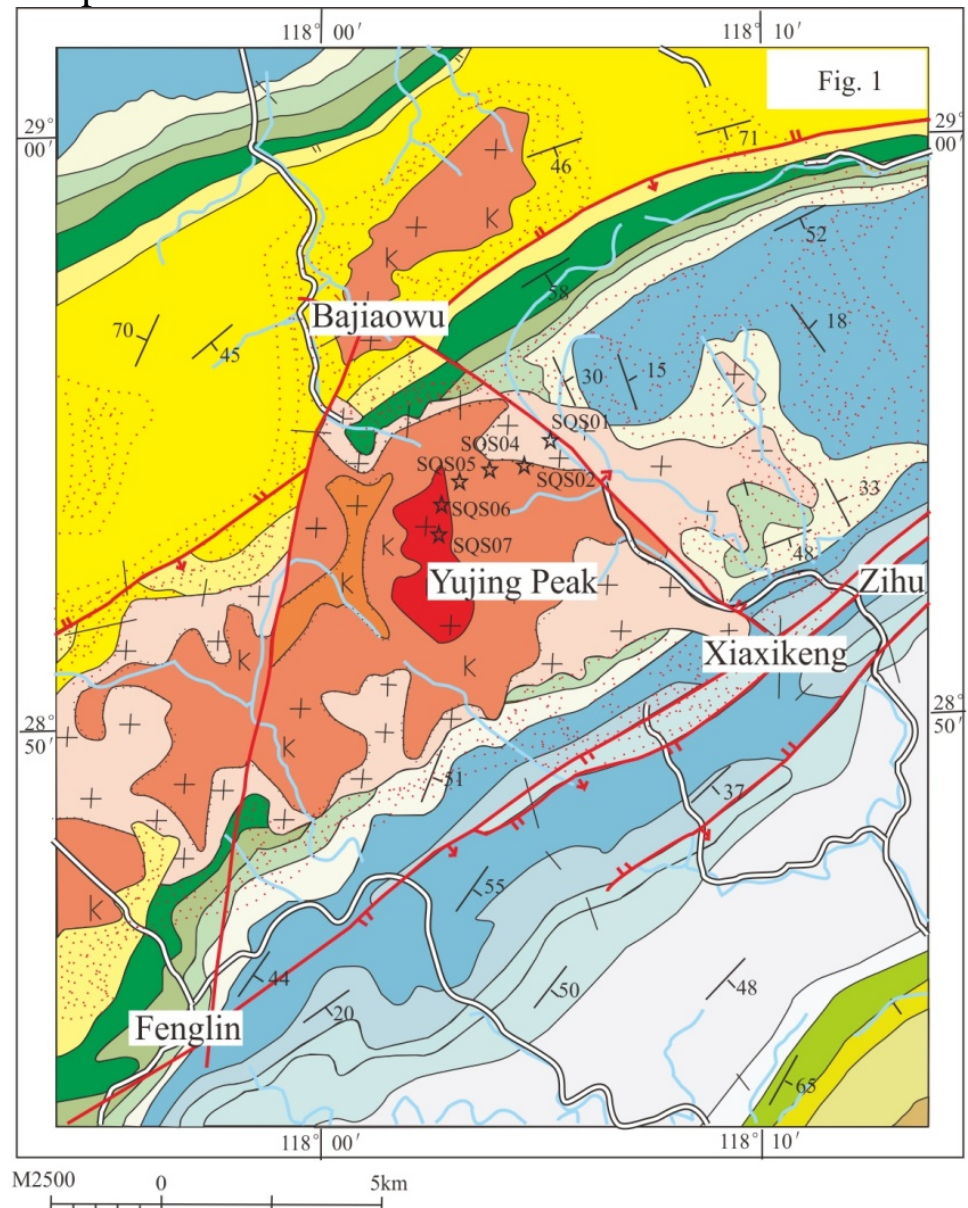

\begin{tabular}{|c|c|c|c|c|c|c|c|}
\hline $\mathrm{D}_{3} x h$ & Xihu Formation & $\mathrm{O}_{3} \mathrm{w}$ & Wenchang Formation & $\mathrm{O}_{t, n}, n-h l$ & $\begin{array}{l}\text { Ningguo Formation and } \\
\text { Hule Formation }\end{array}$ & ${ }_{2} y$ & Yangliugang Formation \\
\hline $\mathrm{s}, k-t$ & $\begin{array}{l}\text { Kangshan Formation and } \\
\text { Tangjingwu Formation }\end{array}$ & $\mathrm{O}, c$ & Changwu Formation & $0 y$ & Yinzhubu Formation & h-d & $\begin{array}{l}\text { Hetang Formation and } \\
\text { Dachengling Formation }\end{array}$ \\
\hline $\mathrm{S}_{\mathrm{s}} h$ & Helixi Formation & $0, h n$ & Huangnigang Formation & ${ }_{3} 0, x$ & Xiyangshan Formation & $Z_{1} l-Z_{,}, p$ & $\begin{array}{l}\text { Lantian Formation and } \\
\text { Piyuancun Formation }\end{array}$ \\
\hline $\mathrm{S}_{1} x$ & Xiaxiang Formation & $\mathrm{O}_{3} y w$ & Yanwashan Formation & ,hy & Huayansi Formation & $\begin{array}{l}\mathrm{Nh}, \mathrm{x} \\
-\mathrm{Nh}, n \\
\end{array}$ & $\begin{array}{l}\text { Xiuning Formation and } \\
\text { Nantuo Formation }\end{array}$ \\
\hline$B \xi\rangle_{s}^{3(b)}$ & $\begin{array}{l}\text { Fine-grained Porphyritic } \\
\text { blotite granite }\end{array}$ & & $\mathrm{K}$-feldspar granite & $\beta \xi_{5}^{(a)}$ & $\begin{array}{l}\text { Medium and coarse } \\
\text { grained Porphyritic } \\
\text { blotite granite }\end{array}$ & $\beta 5 y_{3}^{3(\infty)}$ & $\begin{array}{l}\text { Medium and fine grained } \\
\text { Porphyritic blotite granite }\end{array}$ \\
\hline 5 & Measured fault & $\cdots$ & Hornfels belt & 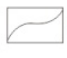 & geological boundary & rd & $\begin{array}{l}\text { Parallel unconformable } \\
\text { boundary line }\end{array}$ \\
\hline … & Facies boundaries & $r_{30}$ & Rock occurrence & मे & Sampling position & & \\
\hline
\end{tabular}

Figure 1 Regional geological map of Mt. Sanqingshan

\section{Experiments}

It has been widely accepted to analyze the uplifting-denudation process of mountains or orogenic belts by thermal-chronology.

All the samples are collected from the fresh outcrops in Mt. Sanqingshan granite batholiths (Main stage) and Yujing Peak granite stock (Supplement stage). A portable GPS was carried to measure the elevation and location of sampling points. Each sample is heavier than $3 \mathrm{~kg}$.

Granite hand specimens could be divided into 3 types: Coarse and medium grained granite (Figure 2a), Medium and fine grained granite (Figure 2b), Fine-grained granite(Figure 2c). Their compositions are roughly the same, but the mineral content is slightly different. 

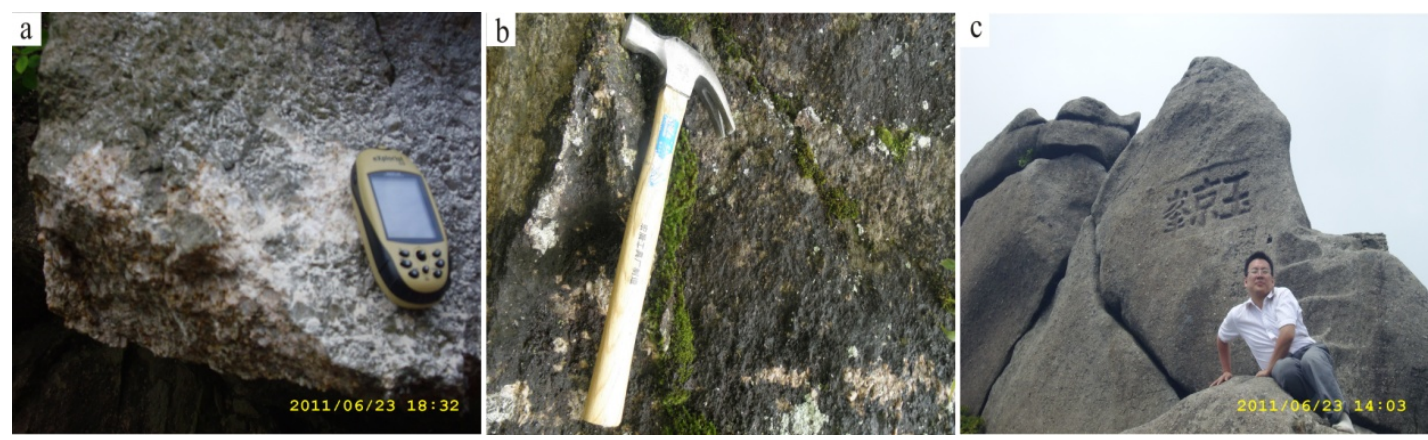

Figure 2 Granite in different locations of Mt. Sanqingshan

The experiments have been made at the Institute of High Energy Physics, Chinese Academy of Sciences. The following steps were operated (Green 1986). The samples were crushed first. The crushed particle sizes should match with the mineral grain sizes in the rock. After primary separation by using the traditional methods, and further separation by using lectromagnetic and heavy liquid, the particles of apatite and zircon were separated. The single mineral particles were placed on the glass, fixed with drops of epoxy resin. After grinding and polishing, optical sheets were made. Spontaneous apatite tracks were revealed by using HNO3 (concentration 7\%) for 30 seconds at $25^{\circ} \mathrm{C}$, and zircon tracks were revealed by using $\mathrm{NaOH}(8 \mathrm{~g})+\mathrm{KOH}(11.5 \mathrm{~g})$ for 33 hours at $220^{\circ} \mathrm{C}$. a low-uranium muscovite external detector, tightly wrapped with a single mineral, was put together into the reactor for irradiation by using HF (concentration 40\%) to revealed induced tracks for 20 seconds. Neutron fluency was monitored by using CN5 uranium dosimeter glass. Densities and confined lengths of fission tracks in both natural and induced fission track populations were measured with microscope at high magnification. Only those crystals with prismatic sections parallel to the c-crystallographic axis were accepted for analysis as these crystals have high etching efficiency. Age value of standard samples ( $\rho s / \rho i)$ was measured with an external detector and $\rho d$ was recorded by standard uranium glass muscovite. Central ages were calculated according to Zeta constant $(\xi)$ recommended by International Union of Geological Sciences and standard fission track age equation.

$\chi 2$ is an indicator to evaluate the probability that all age grains analyzed belong to the same age group(Galbraith, 1981). If $\mathrm{P}(\chi 2)>5 \%$, it indicates that the fission track age represent the age of the last thermal event, If $\mathrm{P}\left(\chi_{2}\right)<5 \%$, it indicates that the fission track age of single-grain mineral spreads asymmetrically, then the traditional analysis based on the Poisson-variation is invalid and should be replaced with the "central age", which is essentially a weighted mixed age(Green, 1981).

Seven groups of effective fission track data from the minerals of apatite and zircon have totally obtained (Table 1). 
Table 1. Analysis results of apatite fission track in Mt. Sanqingshan

\begin{tabular}{|c|c|c|c|c|c|c|c|c|c|}
\hline Samples & Elevation & $\begin{array}{c}\text { Particle } \\
\text { Number (n) }\end{array}$ & $\begin{array}{c}\rho_{\mathrm{s}}\left(10^{5} / \mathrm{cm}^{2}\right) \\
(\mathrm{Ns})\end{array}$ & $\begin{array}{c}\rho_{\mathrm{i}}\left(10^{5} / \mathrm{cm}^{2}\right) \\
(\mathrm{Ni})\end{array}$ & $\begin{array}{c}\rho_{\mathrm{d}}\left(10^{5} / \mathrm{cm}^{2}\right) \\
(\mathrm{Nd})\end{array}$ & $P\left(\chi^{2}\right)$ & $\begin{array}{l}\text { Central } \\
\text { age (Ma) }\end{array}$ & $\begin{array}{c}\text { Pooled } \\
\text { Age (Ma) }\end{array}$ & $\begin{array}{l}\mathrm{L}(\mu \mathrm{m}) \\
(\mathrm{N})\end{array}$ \\
\hline SQS01 & $415 \mathrm{~m}$ & Apatite 32 & 2.259 (246) & $\begin{array}{l}19.152 \\
(2086)\end{array}$ & $\begin{array}{l}20.93 \\
(9117)\end{array}$ & 4.3 & $43 \pm 4$ & $43 \pm 4$ & $\begin{array}{c}12.4 \pm 2.1 \\
(33)\end{array}$ \\
\hline SQS02 & $611 \mathrm{~m}$ & Apatite 29 & 1.334 (223) & $\begin{array}{l}9.527 \\
(1593)\end{array}$ & $\begin{array}{l}20.041 \\
(9117)\end{array}$ & 73.2 & $49 \pm 4$ & $49 \pm 4$ & $\begin{array}{c}12.0 \pm 2.2 \\
(94)\end{array}$ \\
\hline SQS03 & $810 \mathrm{~m}$ & Apatite 15 & $\begin{array}{c}99.816 \\
(991)\end{array}$ & $\begin{array}{c}107.773 \\
(1070)\end{array}$ & $\begin{array}{c}22.95 \\
(13124)\end{array}$ & 7.1 & $109 \pm 9$ & $106 \pm 6$ & \\
\hline SQS04 & $1001 \mathrm{~m}$ & Apatite 6 & $1.294(22)$ & $6.174(105)$ & $\begin{array}{l}18.974 \\
(9117)\end{array}$ & 17.7 & $70 \pm 18$ & $70 \pm 17$ & \\
\hline SQS05 & $1200 \mathrm{~m}$ & Apatite 25 & $\begin{array}{c}154.874 \\
(883)\end{array}$ & $\begin{array}{c}135.756 \\
(774)\end{array}$ & $\begin{array}{c}23.862 \\
(13124)\end{array}$ & 60.0 & $137 \pm 9$ & $137 \pm 9$ & \\
\hline SQS06 & $1409 \mathrm{~m}$ & Apatite 15 & 1.717 (204) & $\begin{array}{l}10.745 \\
(1277)\end{array}$ & $\begin{array}{l}20.397 \\
(9117)\end{array}$ & 3.7 & $57 \pm 7$ & $57 \pm 5$ & $\begin{array}{c}12.0 \pm 2.1 \\
(57)\end{array}$ \\
\hline SQS07 & $1591 \mathrm{~m}$ & Apatite 22 & 2.749 (223) & $\begin{array}{l}13.527 \\
(1593)\end{array}$ & $\begin{array}{l}19.257 \\
(9117)\end{array}$ & 83.2 & $62 \pm 3$ & $62 \pm 3$ & $\begin{array}{c}12.3 \pm 2.0 \\
(94)\end{array}$ \\
\hline
\end{tabular}

Notes: $\rho s$, $\rho$ i and $\rho d$ are spontaneous track density, induced track density, and standard track density respectively; $\mathrm{Ns}, \mathrm{Ni}$, and $\mathrm{Nd}$ are number of spontaneous track, induced track, and standard track respectively; L mean track length $( \pm \sigma) ; \quad P(\chi 2)$ is test value of $\chi^{2}$.

According to the experiment results, the apatite fission track ages range from $(43 \pm 4)$ to $(70 \pm 18)$ Ma, which are relatively concentrated. The calculated $\chi 2$ values for three samples (SQS02, SQS03, SQS04 and SQS07) are bigger than 5\%, whose histograms of single grain ages are characterized with a typical single-peak. However, the calculated $\chi 2$ values for two samples (SQS01 and SQS06) are less than 5\%, whose histograms of single grain ages are characterized with non-typical two-peak. Histograms of apatite track length distribution also show similar characteristics.

\section{Analysis}

The average length for apatite fission track is $12.0 \pm 2.1 \mu \mathrm{m}-12.4 \pm 2.1 \mu \mathrm{m}$. Although there is little change in length, the length is relatively short while the standard deviation is big, reflecting the results of the last single thermal event.

When $\mathrm{P}\left(\chi^{2}\right)$ is less than $5 \%$, Binomfit software is used to decomposed into different age groups. Figure 3 is the radio plot for AFT age grouping for SQS01 and SQS06. 

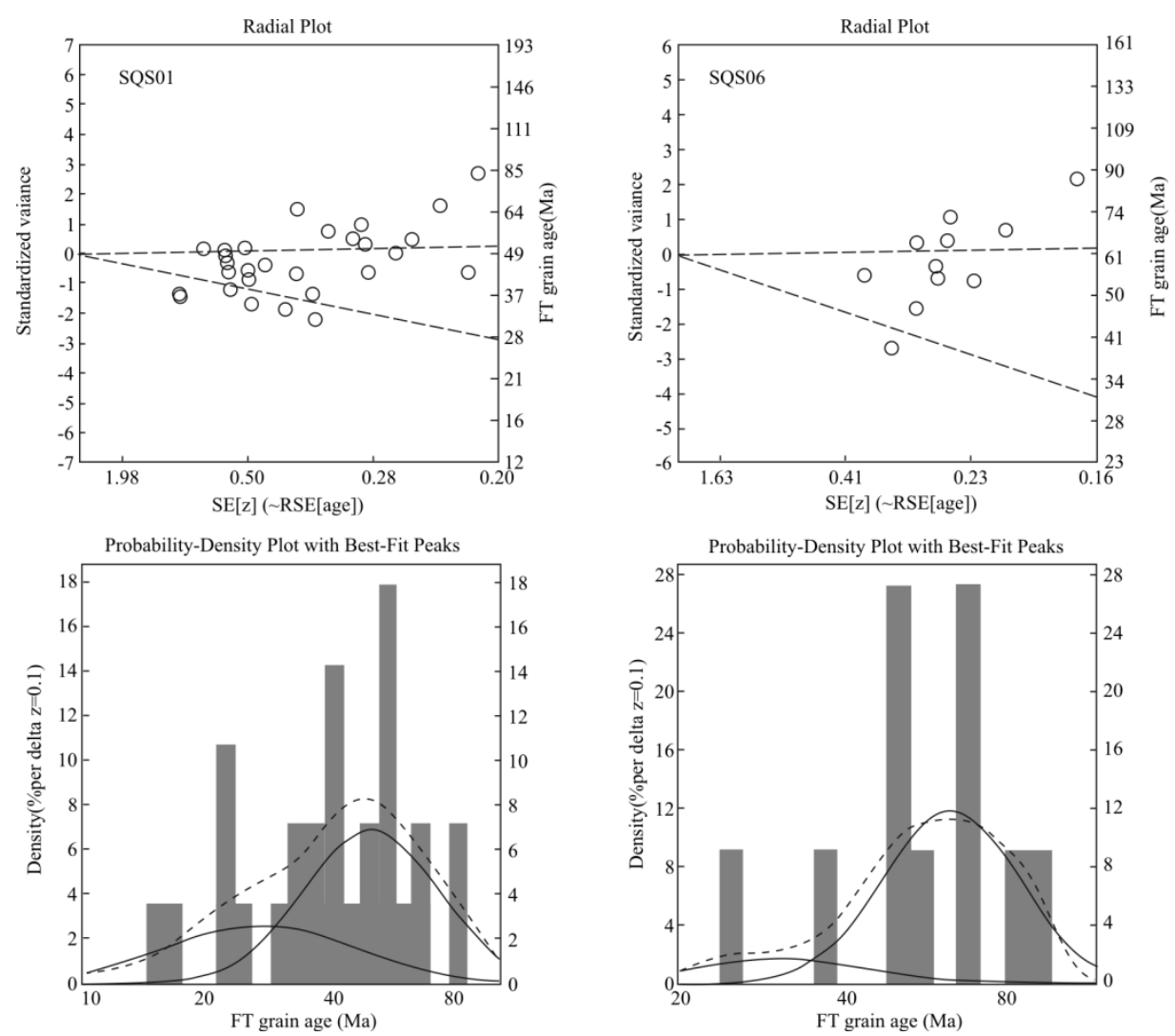

Figure 3 Radial plot for AFT age grouping $\mathrm{P}\left(\chi^{2}\right)<5 \%$

Three age groups can be identified in the age histogram: 25Ma, 50Ma and 70Ma. These age groups are related to the uplifting-denudation processes involved in forming ancient multilevel denudation planes at the sea level about 900m, 1200m, 1500m respectively (Ye et al. 2012).

The initial conditions of the inverse modeling have been determined according to the basic geological factors and parameters of apatite fission track. By using AFT Solve software (Ketcham et al. 1999, 2000), the inverse thermal history modeling of Mt Sanqingshan has been conducted (Figure 4).

The starting time of the modeling depends on the fission track age of the samples. In this case, it is from 90Ma (Late Cretaceous) to the present. The temperature is from $130^{\circ} \mathrm{C}$, which is higher than apatite partial annealing zone (PAZ), to the present surface temperature.

Modeling reveals that the thermal evolution history in Mt. Sanqingshan can be generally divided into four stages: (1) approximately 90Ma to 60Ma: The temperature is high, remaining above $100{ }^{\circ} \mathrm{C}$, which is at the bottom of apatite fission track annealing zone; (2) from 60Ma to 40Ma: it has experienced a rapid cooling from $120-100^{\circ} \mathrm{C}$ down to $95-85^{\circ} \mathrm{C}$; (3) from about $40 \mathrm{Ma}$ to $15 \mathrm{Ma}$ : it has experienced a slow cooling, during which the temperature has dropped from the $95-85{ }^{\circ} \mathrm{C}$ approximately to $80^{\circ} \mathrm{C}$; (4) from the $15 \mathrm{Ma}$ to the present: it is a more rapid cooling period, and the temperature dropped from about $80^{\circ} \mathrm{C}$ to the present surface temperature, i.e. $12^{\circ} \mathrm{C}$ or so. 


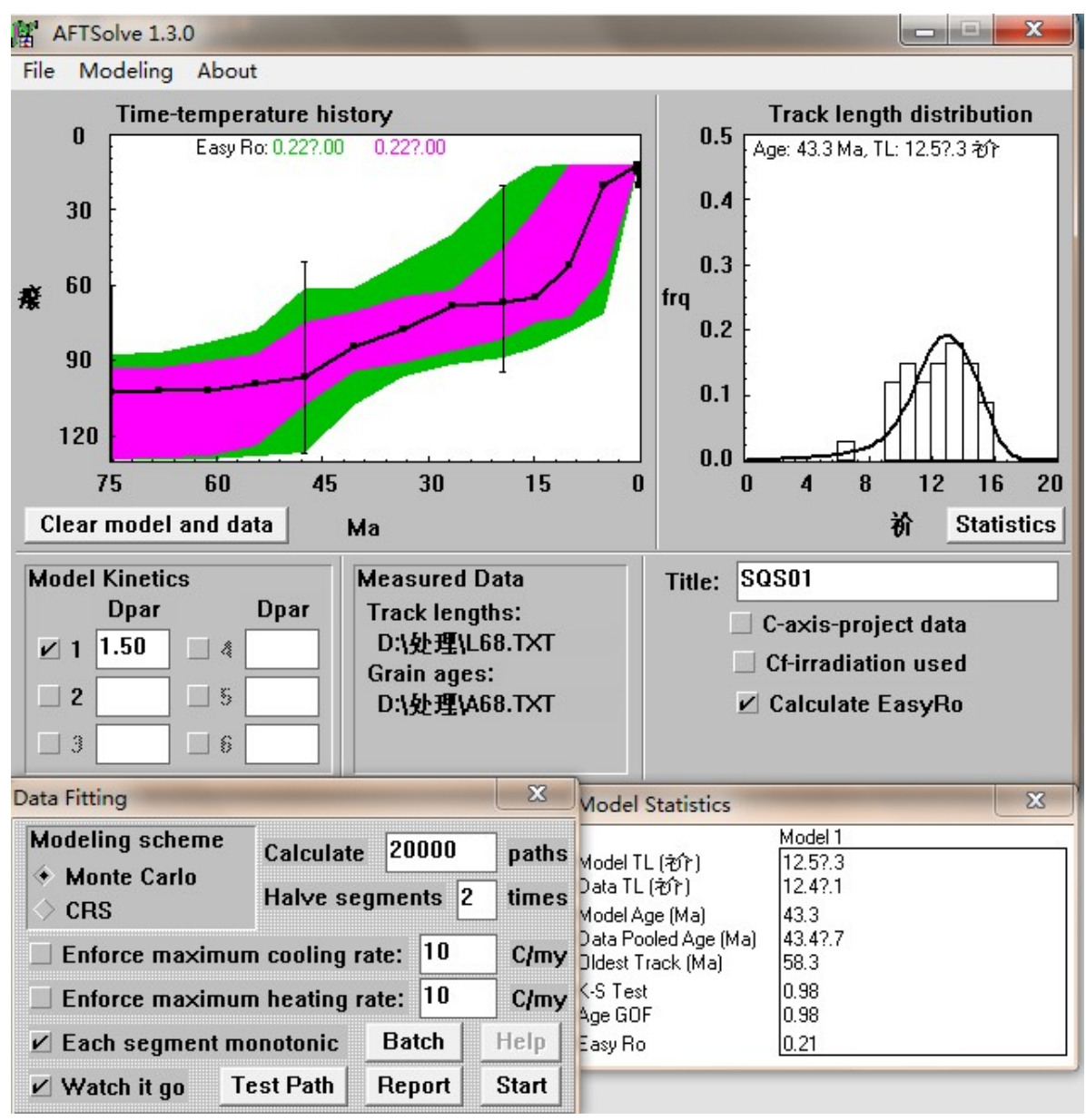

Figure 4 Screenshot of thermal history modeling of Samples

Taking the average 62Ma as a dividing point between stage 1 and stage 2 , and $105^{\circ} \mathrm{C}$ as the average temperature in stage 1 , then the temperature dropped $145^{\circ} \mathrm{C}$ and the cooling rate was $1.95^{\circ} \mathrm{C} / \mathrm{Ma}$ during first stage $(137-62 \mathrm{Ma})$. In stage 2, the temperature dropped $20^{\circ} \mathrm{C}$ and the cooling rate was $1.17^{\circ} \mathrm{C} / \mathrm{Ma}$ during second stage (62-45Ma). In stage 3 , the temperature dropped $10^{\circ} \mathrm{C}$ and the cooling rate was $0.35^{\circ} \mathrm{C} / \mathrm{Ma}$ during third stage (45-18Ma). In stage 4 , the temperature dropped $68^{\circ} \mathrm{C}$ and the cooling rate was $3.72^{\circ} \mathrm{C} / \mathrm{Ma}$ during fourth stage (18Ma-the present). Obviously, stage 4 had the highest cooling rate than the other three stages. The average cooling rate was $1.81^{\circ} \mathrm{C} / \mathrm{Ma}$ in four stages.

Suppose the average geothermal gradient in Eastern China Oregon is $35^{\circ} \mathrm{C} / \mathrm{km}$ (Yuan et al. 2011), the cooling rate of the first stage is $145^{\circ} \mathrm{C}$, the time span is $75 \mathrm{Ma}$, the uplifting extent and rate in Mt. Sanqingshan is $4.14 \mathrm{~km}$ and $0.056 \mathrm{~mm} / \mathrm{a}$ respectively; the cooling rate of the second stage is $20^{\circ} \mathrm{C}$, the time span is $17 \mathrm{Ma}$, the uplifting extent and rate in Mt. Sanqingshan is $0.57 \mathrm{~km}$ and $0.034 \mathrm{~mm} / \mathrm{a}$ respectively; the cooling rate of the third stage is $10^{\circ} \mathrm{C}$, the time span is $27 \mathrm{Ma}$, the uplifting extent and rate in Mt. Sanqingshan is $0.29 \mathrm{~km}$ and $0.011 \mathrm{~mm} / \mathrm{a}$ respectively; the cooling rate of the fourth stage is $68^{\circ} \mathrm{C}$, the time span is $18 \mathrm{Ma}$, the uplifting extent and rate in Mt. Sanqingshan is $1.94 \mathrm{~km}$ and $0.11 \mathrm{~mm} / \mathrm{a}$ respectively.

The average uplifting rate is about $0.052 \mathrm{~mm} / \mathrm{a}$. The cumulative amount of uplifting was $6.94 \mathrm{~km}$, which is consistent with conclusions from the viewpoint of petrology. Zhang et al. (2007) figured out that the granitic magma emplacement depth in Mt. Sanqingshan was about $6 \mathrm{~km}$, in another word, Mt. Sanqingshan was uplifted at least $6 \mathrm{~km}$. If we take the elevation of sampling points into account, the conclusions about uplifting extent drawn from AFT and petrology are very close.

\section{Conclusions}

Rock uplifting (U) is the uplifting of a rock with respect to the eustatic sea level, with the relationship: 


$$
\mathrm{U}=\mathrm{D}+\Delta \mathrm{H}+\Delta \mathrm{s} .1
$$

Here $\mathrm{U}$ is the amount of denudation; $\Delta \mathrm{H}$ is elevation difference between the current surface and ancient surface; $\Delta$ s.l. is sea level change (England et al. 1990). By calculating, the average uplifting is $3500 \mathrm{~m}$.

The average amount of denudation can be obtained by the formula (Brown 1991):

$$
\Delta \mathrm{E}=\left(110 \pm 10^{\circ} \mathrm{C}-\mathrm{Ts}\right) / \mathrm{G}+\mathrm{d}
$$

Here $\Delta \mathrm{E}$ is the average denudation amount; Ts is the ancient surface temperature; $\mathrm{G}$ is the paleo-geothermal gradient; $d$ is the elevation difference between the bottom of fission track annealing zone and the current surface. Therefore the average denudation is $2500 \mathrm{~m}$.

Since 56Ma i.e., the average apatite fission track ages in Mt. Sanqingshan, the average uplifting rate and denudation rate difference is $0.005 \mathrm{~mm} / \mathrm{a}$, and the average amount of uplifting and denudation difference is $1000 \mathrm{~m}$, which is very close to the average elevation- about $1000 \mathrm{~m}$ in Mt. Sanqingshan. This is the process from the magma emplacement $6 \mathrm{~km}$ underground to present medium -sized mountain.

\section{Acknowledgements}

The research was financially supported by the Administration Committee of Mt. Sanqingshan Geopark.

\section{References}

[1]. Brown, R.W., 1991, Backstacking apatite fission-track "stratigraphy": A method for resolving the erosional and isostatic rebound components of tectonic uplift histories: Geology, v. 19, p. 74-77.

[2]. England, P., and Molnar, P., 1990, Surface uplift, uplift of rocks, and exhumation of rocks: Geology, v.18, p.1173-1177.

[3]. Ketcham, R.A., Donelick, R. A., and Donelick M.B., 2000, AFT Solve: A program for multi-kinetic Modeling of apatite fission-track data: Geological materials research, v2, p.l-32.

[4]. Ye, Z.H., Liu, J.Q., Yin, G. S., Chen, A.Z., and Wang, M., 2012, Record of geological events in Mount Sanqingshan National Geopark in Jiangxi: Acta Geoscientica Sinica, v. 33, p. 236-244(in Chinese with English abstract).

[5]. Zhang, Z.C., Jian, P., and Wei, H.R., 2007, SHRIMP ages, geology, geochemistry and petrogenetic type of granites from the Sanqingshan Geopark, Jiangxi Province: Geological Review, v. 53, p. 28-40(in Chinese with English abstract). 